\title{
Effect of individual factors on youth entrepreneurship - a study of Uttarakhand state, India
}

\author{
Lalit Sharma ${ }^{*}$ and Pankaj Madan ${ }^{2}$
}

*Correspondence: Ialit_10000@
yahoo.com
${ }^{1}$ Quantum School of Business, 22
km Milestone, Roorkee- Dehradun
Highway, Roorkee 247667
Uttarakhand, India
Full list of author information is
available at the end of the article

available at the end of the article

\begin{abstract}
In this study we have tried to examine the effect of individual factors like intelligence, past self employment experience, past work experience and educational course of professional students on their decision to take up entrepreneurship as a career choice. It is a quantitative study wherein we have taken data of 530 young students studying in the final year of various professional courses (MBA/PGDM, MCA, B.Tech, BHMCT \& B.Pharm) of Uttarakhand state of India. The student target population chosen for this study was in the age group of 20-24 years. The male \& female ratio of this study was $75 \& 25$ respectively. Data analysis has been done using Cross tabulation and Chi square test. The results showed that past self-employment experience has a negative impact on student's entrepreneurial inclination. No relationship was seen between the work experience (typically less than 3 years) and entrepreneurial inclination. Students scoring high on intelligence were seen to have no or little entrepreneurial inclination and students who were in MBA/ PGDM, MCA \& BHMCT courses were little better inclined towards entrepreneurship in comparison to the rest of the courses.

Keywords: Entrepreneurship; Career choices; Individual factors; Youth entrepreneurship in Uttarakhand; Career intentions; Developing country; Entrepreneurial inclination
\end{abstract}

\section{Background}

Governments and local communities across the world have recognized that key to building prosperity and stimulate regional growth is fostering entrepreneurship among their people especially youth. Youth entrepreneurship has become a topic of interest for research scholars and also a subject of major concern for the Governments. Promoting youth entrepreneurship will not only help in reducing unemployment but more importantly make young people understand that they have alternatives to create their own destiny by starting their own companies and they need not keep waiting to get a job.

Uttarakhand emerged as the 27th state of the Republic of India on 9th November 2000. Uttarakhand is a place with great diversity where snow-clad mountains, green hills, fertile valleys, flowing rivers several natural lakes add to its beauty. The place is an abode to several highly venerated pilgrimage places. Uttarakhand has lately been 
facing the challenges of increased unemployment and immigration which has prompted the state government to take appropriate measures to build youth entrepreneurship in the state. A host of incentives have been proposed by the state government to build entrepreneurship in the state. The Special Integrated Industrial Promotion Policy 2008 for hilly \& remote areas of Uttarakhand offered a series of sops for promotion of industries in Uttarakhand. Some of the major provisions under the policy include providing $25 \%$ subsidy on investment in plant and machinery; in case of mega projects $50 \%$ cost of infrastructure is met by state. Government reimburses $75 \%$ of the expenses incurred on Intellectual property rights, ISO Certifications, ISI Certifications, Quality marking, FPO Licenses and Trademarks to a maximum of Rs. 1 Lac. All new industrial units engaged in manufacturing and production of goods including the industrial enterprises engaged in the activities in service sector are entitled for 100 percent rebate on electric bills for a period of ten years. Although the existing entrepreneurs have expanded their businesses because of these sanctions, a lot of big corporate houses were also lured into the state by these attractive economic policies but the incentives does not seem to affect the entrepreneurial inclination of the youth of Uttarakhand. In fact, nothing significant is seen in terms of entrepreneurship development from within the state. Some of the major perceived barriers to youth entrepreneurship identified in Uttarakhand are lack of capital, no prior experience and lack of guidance (Sharma \& Madan, 2013). The growing educated, idle, jobless and underemployed youth is a major societal problem which if not tackled and controlled timely could turn into a bigger trouble for the state government. This particular study tends to investigate the effect of individual factors like past experience, education and intelligence of the youth in developing entrepreneurial inclination. Individual factors play a significant role in entrepreneurship development and a lot of work has been done globally on these factors but we have tried to reassess it from the context of Uttarakhand.

Career choice is a cognitive process driven by beliefs, attitudes and experiences and prior research confirms that entrepreneurial careers fit a similar pattern (Davidsson, 1991; Katz, 1992; Shaver \& Scott, 1992). Simon (1979) posited that the formulation of goals of an individual would depend on existing knowledge and experience of the decision maker. Simon further supports the view that past experience is playing a role in career goal setting and decision making. A rise in experience implies "an increased awareness of what is likely to happen in the future, as well as increased contemplation of the behavior and its consequence" (Pomery et al. 2009). Individuals are less reactive and more thoughtful when they gain experience (Pomery et al. 2009). Students with previous working experiences are also seen to be interested in entrepreneurship. The study by Ghazali, et al. (1995) and Othman et al. (2006) showed that university students with working experiences have increased probability of being entrepreneurs. This supported the view that having previous working experience is an advantage for students as they acquire better knowledge about business creation, develop good networking which helps them in acquiring needed sources to confidently launch a venture. Interestingly, these students were studying in the non-business areas, supporting the findings of Kristiansen and Indarti (2004) who indicated that there is no significant impact of educational background of students on their entrepreneurial inclination. Prior experience as an entrepreneur has also been linked with the increased propensity of adults to start a new venture (Boyd \& Vozikis, 1994; Cooper et al. 2004) where as a 
similar study conducted in Srilanka found that contribution of self employment experience for developing entrepreneurial intention among the business students is relatively low (Nishantha, 2009). This shows that the factor is probably dependant upon the region. Entrepreneurship education has been recognized as one of the vital determinants that could influence students' career decisions (Kolvereid \& Moen 1997; Peterman \& Kennedy, 2003).Where as according to Chinoso (2010) technical and vocational education are the only alternative forms of education and training that can guarantee entrepreneurship development and job creation for youths. Another study by Wadhwa et al. (2010) on immigrant tech founders and U.S. born engineering and technology company founders found that although they were well-educated there was a significant difference in the types of degrees these entrepreneurs obtained. We have tried to understand the global perspective on these individual factors and broaden the research outcomes in these areas by evaluating the same in the context of Uttarakhand.

\section{Purpose of the study}

In spite of the increasing recognition of entrepreneurship as a source of job creation, regional development, and economic dynamism in a rapidly globalizing world, there has been no systematic attempt to look at it from the youth perspective. Youth entrepreneurship is picking up fast not only in developed countries but also in developing countries like India. Poor rate of entrepreneurship in the Uttarakhand state may be attributed to several different factors. With the state government having provided a host of incentives for industrial development, the rate of youth entrepreneurship remains to be low. Educated, skilled \& unskilled youth need to turn into entrepreneurs. By January 2013, a total of 7,03000 people were registered with different employment exchanges of Uttarakhand, desperate to take up any job. The unregistered unemployed youth of Uttarakhand is not included in this number. This desperation of unemployed youth was evident at a recent drive for the recruitment of home-guards in the state, when scores of post-graduates turned up for interviews. The basic requirement was only eighth standard. Unemployment is giving fuel to immigration. The 2011 Census reveals migration from all 13 hill districts of Uttarakhand state. The state government is trying its best to foster entrepreneurship amongst the youth. Presently there is a general lack of accurate and systematic data on youth, especially as it relates to youth entrepreneurship. This study is an attempt to understand various individual factors that affect the preferred career choice decision of young students especially on becoming an entrepreneur.

\section{Review of literature}

The literature review has clearly emphasized the importance of studying 'intentions' in entrepreneurship. According to Krueger et al. (2000), entrepreneurial activity can be predicted more accurately by studying 'intention' rather than 'personality traits', 'demographic characteristics' or 'situational factors'. The theory of planned behavior contends that intentions are a function of three sets of factors: attitudes, subjective norms, and perceived behavioral control. Given that the decision to found a firm can be regarded as reasoned action or planned behavior, the relationship between intentions and actual behavior should be fairly strong (Ajzen, 1991; Sheppard et al. 1988). Several authors (Reynolds, 1991; Stanworth et al. 1989) have emphasized that personal background 
characteristics have a more reliable influence on the decision to found one's own firm than psychological traits. The literature review for this study has been divided into four parts. The first part comprises of the studies related to the effect of past selfemployment experience of an individual on entrepreneurship development. The second part deals with the literature review on effect of past experience in job on building entrepreneurship. The third part comprises of the review of work on effect of intelligence of an individual on entrepreneurship development and finally we have tried to explore those works in which the effect of an educational background or the courses studied have any impact on entrepreneurship development.

Research has shown that an individual's past business experience influences their decision making and business performance (Dyke et al. 1992). Several studies (Kets de Vries, 1977; Hisrich \& Brush 1984; Scott \& Twomey, 1988; Scherer et al. 1989; Taylor \& Thorpe, 2004) exploring the reasons why individuals become entrepreneurs have identified previous exposure to business, role models and networks as important. Individuals who have family members or close friends who are entrepreneurs tend to be more likely to start their own business than those individuals who have not experienced the same level of exposure to entrepreneurship (Collins \& Moore, 1970; Cooper \& Dunkelberg, 1984). Shapero \& Sokol (1982) and Praag \& Ophem (1995) suggested that willingness and presence of an opportunity are both necessary conditions for selfemployment to occur and both were found to be enhanced through experience gained in entrepreneurship. Krueger \& Brazeal (1994) posited that an individual's situational perceptions based on past and current experiences can influence their entrepreneurial intention. Bandura (1986) has linked previous entrepreneurial experience to self efficacy and derived that previous entrepreneurial experience may lead to increased levels of entrepreneurial self-efficacy given the opportunities provided for role-modeling and learning through doing. The entrepreneurial inclination is an attitudinal measure which is related to both Shapero \& Sokol (1982) and Ajzen's (1991) theories and is proposed to be influenced by students' previous entrepreneurial experience. Several researchers (Shapero \& Sokol, 1982; Krueger \& Carsrud, 1993; Fayolle \& Degeorge, 2006; McMullen \& Shepherd, 2006) have studied entrepreneurship education and previous entrepreneurial experience together and found both of them as important motivators and contributors to the formation of entrepreneurial intentions provided there is a feasibility of entrepreneurship \& desirability of individual. Despite of all the positive studies noted above the results of Tkachev \& Kolvereid (1999) indicated that demographic characteristics as family background and past self-employment experience affected entrepreneurial intentions however only through attitudes, subjective norms and perceived behavioral control. McStay (2008) supported that students in the entrepreneurship subject with 'low' previous entrepreneurial experience had a greater intention to be self employed than those students with 'high' previous entrepreneurial experience. Another study conducted in Srilanka found that contribution of self employment experience for developing entrepreneurial intention among the business students is relatively low (Nishantha, 2009). This clearly highlights that regional difference is an important factor which needs to be considered in determining the effect of self employment experience on youth entrepreneurship. Accordingly we have tried to understand the relationship between the two in context of Uttarakhand and formulated our first hypothesis. 
Hypothesis H1a: Previous entrepreneurial experience has no influence on student's entrepreneurial inclination.

Authors (Matthews \& Moser, 1995; Scott \& Twomey, 1988) have suggested that work experience is influential in one's interest in an entrepreneurial career and in building entrepreneurial competencies (Bird, 1995). Different authors have put forward their explanations as to how it is helpful. Krueger \& Brazeal (1994) indicate that prior work experience could potentially improve one's skills and abilities, particularly in recognizing business opportunities. Maxwell \& Westerfield (2002) argue that an entrepreneur's innovativeness, which is an aspect of his/ her competencies, depends largely on the level of his/her formal education as well as prior managerial experience. Box et al. (1994) and Chandler (1996) opined that industry experience may be most valuable in identifying the tangible and intangible needs of the early stage venture. Hart et al. (1995) posit that industry knowledge and related industry networks are important assets in specifying the new venture's need for resources, finding those resources, selecting partners and structuring flexible contracts with resource providers. The study by Samuelsson (2001) affirmed that experience in a similar industry was positively related to growth in innovative ventures. Lee \& Tsang (2001) expressed that industrial and managerial experience is the dominating factor affecting venture growth. Venture capitalists note that industry experience that is tightly related with the products, processes, or business models proposed for financing as the most important characteristic of the team (Smith \& Smith, 2000). Various authors (Shrader \& Siegel, 2007; Oakey, 2003) have also emphasized upon the importance of technical industry experience in building entrepreneurship. One of the recent studies by Wadhwa et al. (2009) also emphasized upon the industry experience to be relevant to entrepreneurs. The researchers surveyed 549 company founders in a variety of industries, including aerospace, defense, computers, electronics, health care, and services. The majority of respondents (75.4\%) had worked as employees at other companies for more than six years before launching their own companies. Nearly half $(47.9 \%)$ launched their first companies with more than ten years of work experience. Significant percentages of respondents started their first companies after working eleven to fifteen years (23.3\%), sixteen to twenty years (14.3\%), or greater than twenty years (10.3\%) for someone else.

Hypothesis H1b: Previous work experience of a student in job has no influence on his entrepreneurial inclination.

Wechsler (1944) defined intelligence as the aggregate or global capacity of the individual to act purposefully, to think rationally, and to deal effectively with his environment. Gardner $(2006,2007)$ argues that intelligence refers to both the personal decisions and potentials of individuals. This potential comes out or develops according to cultural environment, values and opportunities. Similarly Demirel \& Tikici (2010) posited that when education is based on ability and dominant multiple intelligence area rather than trying to fit individuals into particular patterns, left brain and right brain characteristics will be balanced and, accordingly, a society with a strong entrepreneurial spirit will be created. Gilad et al. (1989) surveyed 86 small business owners and 21 managers of small business in New Jersey \& found that entrepreneurs spent more time thinking about business opportunities and development in comparison to their managers thereby supporting the view that entrepreneurs have better cognitive capacity. Authors have put forward different types of intelligence and their effect on entrepreneurs and entrepreneurship. According to 
Hartog et al. (2010) the effect of technical and social intelligence is larger for entrepreneurs than for employees whereas the effects of mathematical and verbal ability are stronger for employees. As per Shane \& Venkataraman (2000) Creative intelligence, in particular, may be a predictor of success in new ventures that compete on the basis of technology. Baum et al. (2001) reported a positive relationship between practical intelligence and entrepreneurial processes and entrepreneurial characteristics. Sternberg (2004) posits that successful entrepreneurship requires a blend of analytical, creative, and practical aspects of intelligence, which, in combination, constitute successful intelligence. According to him successful intelligence, not just a subset of its components (analytical, creative, and practical abilities), is needed for entrepreneurial success. . However another view by Gartner (1988) holds that general intelligence is a person-centric variable that does not go far in explaining differences in entrepreneurs' behavior. To the best of our knowledge there are not many studies on effect of academic intelligence on entrepreneurial intentions. A few studies (De wit \& Van Winden, 1989; Dewit, 1993) have been done on finding a relationship between the IQ Scores and self-employment propensity. The findings showed that IQ Scores measured at age 12 had a positive and significant effect on self employment propensity later in life. Another recent survey on this aspect is done by Wadhwa et al. (2009). The researchers surveyed 549 company founders in a variety of industries and studied the academic performance of the company founders. The survey revealed that 75 percent of the founders ranked their academic performance among the top 30 percent of the high school class, with a majority (52.4 percent) ranking their performance among the top 10 percent. 67 percent founders ranked their academic performance among the top 30 percent of their undergraduate class, but a smaller percentage (37.5 percent) ranked their performance among the top 10 percent. The above study indicates that academic intelligence could be a major factor influencing entrepreneurship among the students. The field calls for more attention from the researchers and better understanding in this area. We investigated the relationship between academic intelligence and entrepreneurial inclination.

Hypothesis H2: Academic intelligence of a student has no influence on his entrepreneurial intentions.

A review of the literature showed that education in general has a positive effect on business success (Douglass, 1976; Robinson \& Sexton, 1994; Vesper, 1990). Peterman \& Kennedy (2003) have emphasized that education programs can significantly change the entrepreneurial intentions of participants. Scott et al. (1998) argued that education plays two fundamental roles in the process of economic wealth. First, education increases the supply of highly educated entrepreneurs in the economy especially in industries that require high levels of education. Second, education improves the effectiveness of potential entrepreneurs through enhancing their interpersonal, management and business skills. Brockhaus \& Horwitz (1986) and Sletten \& Hulaas (1998) explained that since current and future entrepreneurs are younger and less experienced, educational backgrounds are vital to the development of new businesses. Gartner (1988) posited that in encouraging growth of new businesses, education plays a fundamental role. Therefore, it is necessary to understand the behaviors and educations of entrepreneurs who create new businesses. Whereas there are several authors who have supported that business founders/owners were educated than the general public (Douglass, 1976; Cooper \& Dunkelberg, 1987, Robinson \& Sexton, 1994; Foley \& Griffith, 1998; Scott, et al. 1998), there are reports which have confronted the view. Ashmore's (1986) 
reported that the NFIB surveyed 5000 entrepreneurs and found that $40 \%$ had only a high school diploma or less and of that $38 \%$ had never taken a business course. A report by the Small Business Administration (2001) showed individuals with educational level of high school or less established nearly half of the new businesses and over $65 \%$ of the self-employed did not graduate from college. Vesper (1990) and Robinson \& Sexton (1994) concluded that entrepreneurs with a good general education tend overall to be noticeably more successful than those with less favorable education and even more successful when general education is combined with experience. At the same time, they admitted their inability to study the effect of specific types of education as opposed to general levels of education. This sparks the need to understand the 'favorable educational background' for a budding entrepreneurs or what type of education or majors, if any, are more helpful for a person in building entrepreneurial intentions. A lot of authors (Kolvereid \& Moen, 1997; Noel, 1998; Dyer 1994; Watson et al. 1998; Souitaris et al. 2007) have emphasized upon entrepreneurship education as being critical for raising entrepreneurial intentions and entrepreneurship development. But on the contrary Brockhaus (1982) in his study has cited the study of Robidox \& Garnier held in 1973 who studied the level of education of entrepreneurs in high-tech firms. The study showed that the more educated the entrepreneurs, the higher the rate of growth of the firm; however, they found no differences between the performance of those with a management background and those with engineering training. This highlights the need to understand the effect of other education streams on building entrepreneurial inclination and entrepreneurial success. It also needs further investigation on whether any correlation really exists between the two. One of the studies by Kristiansen \& Indarti (2004) affirmed that there is no statistically significant impact of age, gender \& educational background of students on their entrepreneurial inclination. Despite the literature acknowledgment of the benefits of education in general to small business (Douglass, 1976; Kiesner, 1984; Robinson \& Sexton, 1994), a business degree may not necessarily be essential to successfully start and operate a business. College education, however, may help business owners and managers to understand and use such concepts as business plan, marketing strategy, locating and financing a business, dealing with legal issues, and managing human resources (Ashmore, 1986; Noll, 1993). Douglass (1976) in his study conducted on 153 owner-operators of firms could not found any significant correlation between educational background and growth rate. Wadhwa et al. (2010) surveyed 652 U.S. born chief executive officers and heads of product development in 502 engineering and technology companies established from 1995 through 2005. These companies had more than $\$ 1$ million in sales, twenty or more employees, and company branches with fifty or more employees. The results showed that nearly half of all these people had degrees in science, technology, engineering and mathematics (STEM) related disciplines and only one third held degrees in business, accounting, and finance. Finally we would also like to refer to Brockhaus \& Horwitz's (1986) studies which showed that different characteristics of business founders including educational background are associated with what kind of business to start. Thus the study suggested that educational backgrounds associated with a service business might be different from those associated with a manufacturing business.

Hypothesis H3: Students studying different courses have different entrepreneurial inclinations. 


\section{Data analysis}

Each of the hypotheses generated has been individually tested using various analytical tools through SPSS 16 software.

\section{Research methodology}

We have used quantitative research method to conduct this study. Self administered questionnaire was developed \& used as the main data-gathering instrument. The target respondents were the final year students of Uttarakhand studying in B. Tech., MBA, PGDM, BHMCT, B.Pharm. and MCA courses, The sampling method used in this research is proportionate stratified sampling. The whole universe of the target respondents was nearly 20,300. To avoid skewness, the universe was broadly divided into two categories. The first category of students were those who had studied Entrepreneurship as a subject in their professional course and the second category of students did not study Entrepreneurship subject. The percentage of category 1 was approximately $15 \%$ and the percentage of category 2 was approximately $85 \%$ accordingly for a size of population which falls in the range of 20,000 , the sample size for a $95 \%$ confidence level when parameter in population is assumed to be over $85 \%$ or under $15 \%$, and with a reliability of $\pm 3 \%$ the sample size suggested is 530 (Zikmund, 2003). Accordingly the sample size taken for this research is 530. Based upon their prevalence in the universe, total number of seats in Uttarakhand state of each of the following courses - MBA, MCA, B.Tech., B. Pharm and BHM\&CT were determined. These seats were then converted into the equivalent ratio of the sample size and finally separate samples were drawn from each course in order to properly represent the population.

\section{Testing hypothesis $\mathrm{H} 1 \mathrm{a}$}

Previous entrepreneurial experience has no influence on student's entrepreneurial inclination.

To test the above hypothesis, researcher has used Chi-square test. A direct question regarding whether they have any prior experience of doing business was asked from the students (Table 1).

Cross tabulation displays that out of 530 respondents 82 respondents had prior experience of doing business while rest 448 respondents had no prior experience of doing business (Table 2).

Table 1 Cross tabulation

\begin{tabular}{lllll}
\hline & & \multicolumn{2}{c}{ Prior Experience in Business } & Total \\
\cline { 3 - 4 } & & Yes & No & \\
\hline Intention after completion of degree & Start a new business & 11 & 18 & 29 \\
& Seek a suitable job & 57 & 333 & 390 \\
& Go for higher studies & 12 & 66 & 78 \\
& Not yet decided & 2 & 31 & 33 \\
Total & & 82 & 448 & 530 \\
\hline
\end{tabular}

Intention after Degree' and 'Prior Experience in Business'. 
Table 2 Chi-Square test

\begin{tabular}{llll}
\hline & Value & df & Asymp. Sig. (2-sided) \\
\hline Pearson Chi-Square & $13.639^{\mathrm{a}}$ & 3 & .003 \\
Likelihood Ratio & 11.629 & 3 & .009 \\
Linear-by-Linear Association & 5.835 & 1 & .016 \\
N of Valid Cases & 530 & & \\
\hline
\end{tabular}

'Intention after completion of Degree' and 'Prior Experience in Business'.

a. 1 cells $(12.5 \%)$ have expected count less than 5 . The minimum expected count is 4.49 .

The above table contains the output of the Chi-Square test. A low significance value $0.003 \& .009$ of Pearson Chi-square test and Likelihood ratio respectively (typically below 0.05 ) indicates that there is a relationship between the two variables.

$$
\begin{aligned}
& \chi_{\mathrm{cal}}^{2}=13.639 \\
& \chi_{\operatorname{tab}(3,0.05)}^{2}=7.815
\end{aligned}
$$

Since the calculated value of Chi-square is greater than the tabulated value. It is evident that variables 'Prior experience in business' and 'Intention after completion of Degree' are dependent. Hence we reject the hypothesis at 5\% level of significance. This justifies the fact that there is an influence of student's prior experience in business on his entrepreneurial intentions. The crosstabs show that out of 82 students who had prior business experience only 11 were still interested to take entrepreneurship as a career whereas a majority 57 of them wanted to take up a job.

\section{Testing hypothesis $\mathrm{H} 1 \mathrm{~b}$}

Previous work experience of a student in job has no influence on his entrepreneurial inclination.

Based on their previous experience in job, students were divided into five categories Students with no experience, with experience of less than 1 year, with experience between 1 to 2 years, with experience between 2 to 3 years and students with experience of 3 years and above (Table 3).

\begin{tabular}{|c|c|c|c|c|c|c|c|}
\hline & & \multirow[b]{2}{*}{$\begin{array}{l}\text { Yes, } \\
\text { Less than } \\
1 \text { year }\end{array}$} & \multicolumn{4}{|c|}{ Work Experience } & \multirow[t]{2}{*}{ Tota } \\
\hline & & & $\begin{array}{l}\text { Yes, } \\
\text { Between } \\
1-2 \text { years }\end{array}$ & $\begin{array}{l}\text { Yes, } \\
\text { Between } \\
2-3 \text { years }\end{array}$ & $\begin{array}{l}\text { Yes, } 3 \\
\text { Years \& } \\
\text { above }\end{array}$ & $\begin{array}{l}\text { No } \\
\text { experience }\end{array}$ & \\
\hline \multirow[t]{4}{*}{$\begin{array}{l}\text { Intention after completion } \\
\text { of degree }\end{array}$} & $\begin{array}{r}\text { Start a new } \\
\text { business }\end{array}$ & 6 & 2 & 2 & 0 & 19 & 29 \\
\hline & $\begin{array}{r}\text { Seek a suitable } \\
\text { job }\end{array}$ & 46 & 12 & 7 & 0 & 325 & 390 \\
\hline & $\begin{array}{r}\text { Go for higher } \\
\text { studies }\end{array}$ & 9 & 3 & 1 & 0 & 65 & 78 \\
\hline & $\begin{array}{l}\text { Not yet } \\
\text { decided }\end{array}$ & 2 & 1 & 0 & 0 & 30 & 33 \\
\hline Total & & 63 & 18 & 10 & 0 & 439 & 530 \\
\hline
\end{tabular}

Table 3 Cross tabulation 
Table 4 Chi-Square

\begin{tabular}{llll}
\hline & Value & df & Asymp. Sig. (2-sided) \\
\hline Pearson Chi-Square & $10.039^{\mathrm{a}}$ & 9 & .347 \\
Likelihood Ratio & 8.799 & 9 & .456 \\
Linear-by-Linear Association & 2.833 & 1 & .092 \\
N of Valid Cases & 530 & & \\
\hline
\end{tabular}

'Intention after completion of Degree' and 'Work Experience'.

a. 8 cells $(50.0 \%)$ have expected count less than 5 . The minimum expected count is .55 .

Cross tabulation displays the number of cases in each category defined by two grouping variables i.e. 'Work experience' of student and 'Intention after completion of degree'. Out of a total of 530 respondents, 439 respondents do not have any work experience, 63 respondents have experience of less than 1 year, 18 respondents have experience between 1 - 2 years, 10 respondents have experience between $2-3$ years and no student had an experience of 3 years or more. We applied Chi-square test between the variables - 'Work experience' and 'intention after completion of Degree (Table 4).

The above table contains the output of the Chi-Square test. 'A high significance value of 0.347 and 0.456 of Pearson Chi-square test and likely hood ratio respectively (typically above 0.05 ) indicates that there is no relationship between the two variables.

$$
\begin{aligned}
& X_{\text {cal }}^{2}=10.039 \\
& X_{\operatorname{tab}(9,0.05)}^{2}=16.919
\end{aligned}
$$

Since the tabulated value of Chi-square is greater than the calculated value, it is evident that data set obtained by the researcher confirms that variables 'Previous work experience in job' and 'Intention after completion of Degree' are independent. Hence we accept the hypothesis at $5 \%$ level of significance. This justifies the fact that previous work experience of student in job has got no influence on the entrepreneurial intentions of student.

\section{Testing hypothesis $\mathrm{H} 2$}

Academic intelligence of a student has no influence on his entrepreneurial intentions.

To test the above hypothesis, researcher has used Chi-square test. The academic intelligence level of a student has been identified based on his/her academic performance from Class $\mathrm{X}^{\text {th }}$ onwards. Students who have secured through out first division from Class $\mathrm{X}^{\text {th }}$ onwards have been placed in the 'High' category, those who have mostly

Table 5 Cross tabulation

\begin{tabular}{llllll}
\hline & & \multicolumn{3}{c}{ Academic intelligence level } & \\
\cline { 3 - 5 } & & High & Mediocre & Low & \\
\hline Intention after completion of Degree & Start a new business & 10 & 15 & 4 & 29 \\
& Seek a suitable job & 234 & 142 & 14 & 390 \\
& Go for higher studies & 58 & 16 & 4 & 78 \\
& Not yet decided & 23 & 7 & 3 & 33 \\
Total & & 325 & 180 & 25 & 530 \\
\hline Intention after completion of Degree' and 'Intelligence Level'. & & & &
\end{tabular}

'Intention after completion of Degree' and 'Intelligence Level'. 
Table 6 Chi-Square test

\begin{tabular}{llll}
\hline & Value & df & Asymp. Sig. (2-sided) \\
\hline Pearson Chi-Square & $22.655^{\mathrm{a}}$ & 6 & .001 \\
Likelihood Ratio & 21.755 & 6 & .001 \\
Linear-by-Linear Association & 7.196 & 1 & .007 \\
N of Valid Cases & 530 & & \\
\hline
\end{tabular}

'Intention after completion of Degree' and 'Intelligence Level'.

a. 3 cells ( $25.0 \%)$ have expected count less than 5 . The minimum expected count is 1.37 .

secured either first or second division from Class $\mathrm{X}^{\text {th }}$ onwards have been placed in the 'Mediocre' category and those who have mostly secured second and/or third division from class $\mathrm{X}^{\text {th }}$ onwards were placed in 'Low' category (Table 5).

Cross tabulation displays that out of 530 respondents 325 respondents were placed in 'High' academic intelligence category, 180 students were found to be in 'Mediocre' academic intelligence category and 25 students were found to be in 'Low' intelligence level category (Table 6).

Table 6 contains the output of the Chi-Square test. A low significance value 0.001 of Pearson Chi-square test and Likelihood ratio respectively (typically above 0.05) indicates that there is a relationship between the two variables.

$$
\begin{aligned}
& X_{\text {cal }}^{2}=22.655 \\
& \chi_{\operatorname{tab}(6,0.05)}^{2}=12.592
\end{aligned}
$$

Since the calculated value of Chi-square is greater than the tabulated value. It is evident that the variables 'Intelligence level of the student' and 'Intention after completion of Degree' are dependant. This justifies that the intelligence level of a student has an influence on his career choice intentions after completion of degree, specifically being an entrepreneur.

\section{Testing hypothesis $\mathrm{H} 3$}

Students studying different courses have different entrepreneurial inclinations.

To test the above hypothesis, researcher has applied Chi-square test. The hypothesis was tested on the given five professional courses viz. MBA(Master of

\begin{tabular}{|c|c|c|c|c|c|c|c|}
\hline & & \multicolumn{5}{|c|}{ Course } & \multirow[t]{2}{*}{ Total } \\
\hline & & $\begin{array}{l}\text { MBA/ } \\
\text { PGDM }\end{array}$ & $\begin{array}{l}\text { B. } \\
\text { Tech }\end{array}$ & $\begin{array}{l}\text { B. } \\
\text { Pharm }\end{array}$ & MCA & ВНMCT & \\
\hline \multirow[t]{4}{*}{$\begin{array}{l}\text { Intention after completion of } \\
\text { Degree }\end{array}$} & $\begin{array}{r}\text { Start a new } \\
\text { business }\end{array}$ & 7 & 16 & 0 & 4 & 2 & 29 \\
\hline & Seek a suitable job & 65 & 273 & 11 & 33 & 8 & 390 \\
\hline & $\begin{array}{r}\text { Go for higher } \\
\text { studies }\end{array}$ & 13 & 50 & 10 & 4 & 1 & 78 \\
\hline & Not yet decided & 5 & 26 & 0 & 2 & 0 & 33 \\
\hline Total & & 90 & 365 & 21 & 43 & 11 & 530 \\
\hline
\end{tabular}

Table 7 Cross tabulation

'Intention after completion of Degree' and 'Course'. 
Table 8 Chi-square test

\begin{tabular}{llll}
\hline & Value & df & Asymp. Sig. (2-sided) \\
\hline Pearson Chi-Square & $28.155^{\text {a }}$ & 12 & .005 \\
Likelihood Ratio & 24.344 & 12 & .018 \\
Linear-by-Linear Association & .920 & 1 & .338 \\
N of Valid Cases & 530 & & \\
\hline
\end{tabular}

'Intention after completion of Degree' and 'Course'.

a. 9 cells $(45.0 \%)$ have expected count less than 5 . The minimum expected count is .60 .

Business Administration), MCA(Master of Computer Application), B.Tech(Bachelor of Technology), BHMCT(Bachelor of Hotel Management \& Catering Technology) \& B.Pharm(Bachelor of Pharmacy). A selective number of final year students, based on the proportionate stratified sampling were taken from each course and were asked about their preference towards their career choice after the completion of their degree (Table 7).

Out of a total of 530 respondents - 365 respondents were the students of B. Tech, 90 respondents were the students of MBA, 43 respondents were the students of MCA, 21 respondents were the students of B.Pharm and 11 respondents were the students of BHMCT. The above data clearly indicates that a major lot among all the courses is inclined towards seeking a job after completion of their course. However if we compare the ratio of total number of students interviewed in a particular course and their intention after completion of Degree we find that the students studying MCA, BHMCT and MBA/PGDM are seen to be a little more inclined towards taking up entrepreneurship as a career choice in comparison to the rest of the courses (Table 8).

The above table contains the output of the Chi-Square test. 'df' equals the number of categories minus one. A significance value of 0.005 and 0.018 of Pearson Chi-square test and Likelihood ratio respectively (typically below 0.05) indicates dependence of 'course of a student' on 'intention of career choice of student' after completion of degree

$$
\begin{aligned}
& X_{\text {cal }}^{2}=28.155 \\
& X_{\operatorname{tab}(12,0.05)}^{2}=21.026
\end{aligned}
$$

Since the calculated value of Chi-square is greater than the tabulated value. It is evident that the variables 'Course' and 'Intention after completion of Degree' are dependent. Hence we reject the hypothesis at 5\% level of significance. This justifies the fact that the course of a student has an influence on his entrepreneurial inclination.

\section{Result and discussion}

Research indicated that the prior experience of a student in business has an influence on the student's decision to take up entrepreneurship as a career option. Students who had an earlier experience of doing business were seen to be less inclined towards taking up entrepreneurship as a career choice. A very few (13.4\%) of the students with a selfemployment experience showed their intention of starting a business again. Where as a 
majority (69.5\%) of the students with self-employment experience wanted to take up a job after completion of their course. It means that they probably did not have a good experience of doing a business earlier and they did not want to repeat that experience. The result may also indicate that probably doing a business in Uttarakhand is a difficult task or the business environment is not very favorable. While many authors (Shapero and Sokol, 1982; Krueger and Carsrud, 1993; Fayolle and Degeorge, 2006; McMullen and Shepherd, 2006) who have studied entrepreneurship education and previous entrepreneurial experience found both of them as important motivators and contributors to the formation of entrepreneurial intentions, they also emphasized upon the feasibility of entrepreneurship \& desirability of individual. Corresponding to our study it may indicate that entrepreneurship feasibility in Uttarakhand could be low. Our findings complements the study of McStay (2008) who supported that students in the entrepreneurship subject with 'low' previous entrepreneurial experience had a greater intention to be self employed than those students with 'high' previous entrepreneurial experience. Although many authors (Krueger and Brazeal, 1994; Maxwell and Westerfield, 2002; Bird, 1995) have studied the positive influence of prior work experience on building entrepreneurial competencies and venture performance (Samuelsson 2001; Hart et al., 1995). Our results showed that the previous work experience of student in job has got no relationship with the intention of student to become an entrepreneur after completion of degree. The results are in conflict to the suggestion given by Matthews \& Moser, (1995) and Scott \& Twomey, (1988) who put forward that work experience is influential in one's interest in an entrepreneurial career. The reason could probably be attributed to the sample surveyed. Our target sample comprised of $11.8 \%$ students who had experience less than a year, nearly 3.3\% students had work experience between 1 to 2 years and only $1.8 \%$ students had work experience between $2-3$ years. None of the students had an experience of 3 years or more. Contrary to the study by Wadhwa et al. (2009), wherein nearly half (47.9\%) of the company founders launched their first company with more than ten years of work experience and the majority of respondents (75.4\%) had worked as employees at other companies for more than six years before launching their own companies. This indicates that a small amount of experience (typically less than 3 years) is ineffective in creating any entrepreneurial intentions among the students. The research also revealed that there is an influence of intelligence level of student on his career choice intentions of becoming an entrepreneur. The students high on academic intelligence showed low propensity towards becoming an entrepreneurs. Referring to our data only $3 \%$ of the students who were placed in the 'High' intelligence level showed their interest in taking up entrepreneurship as a career whereas $72 \%$ of these students were interested in taking up a job. This could indicate the poor acceptance level of entrepreneurship in the family, society and the culture of Uttarakhand at large and reveal negative attitude of students towards entrepreneurship in comparison to jobs. The students who hold good academic record expect good jobs and are not interested to become entrepreneurs. This finding is in agreement with the recent study by Andrea Asoni (2011) who found that intelligence increases survival rates of existing firms, while it decreases the probability of starting new companies. Another finding of our study reveals that the course of a student which he is studying also has an influence on his decision to become an entrepreneur. Although the students of all the five courses, in general, did not show any significant interest towards 
entrepreneurship, the students of BHMCT (18\%), MCA (9.3\%) and MBA/PGDM (7.7\%) were seen to be little better inclined towards entrepreneurship in comparison to B.Tech (4.3\%) and B.Pharm (0\%). The possible reason behind little better inclination of MBA/PGDM and BHMCT students towards entrepreneurship could be the presence of Entrepreneurship subject taught in the MBA/PGDM and BHMCT courses while this subject is not taught in other courses. The results are consistent with the studies by Kolvereid and Moen (1997), Noel (1998), Dyer (1994), Watson et al. (1998), Souitaris et al. (2007) and other authors who have emphasized upon entrepreneurship education as being critical for raising entrepreneurial intentions and entrepreneurship development. The better inclination of MCA students towards entrepreneurship could possibly be attributed to the Information Technology revolution which has prompted many young minds to begin IT enabled firms with low capital investment. The results support the studies by Sanghvi (1996) who pinpointed the need to provide entrepreneurship training to technical students for accelerated growth of the country. His studies have revealed that if necessary inputs are provided through properly designed training programmes, many young boys and girls can be groomed into successful entrepreneurs. This training will help the students in developing confidence in starting their own businesses and also generate self-employment.

\section{Conclusion}

The prior experience of a student in business has an influence on the student's intention to take up entrepreneurship as a career option. Students who had an earlier experience of doing business were seen to be less inclined towards taking up entrepreneurship as a career choice indicating bad experience and unfeasible business environment. The study revealed that previous work experience of student in job has got no relationship with the intention of student to become an entrepreneur after completion of degree. It highlights that a small amount of experience (typically less than 3 years) is insignificant in creating entrepreneurial intentions. The students who were placed in the 'High category' on academic intelligence were seen to be less inclined towards taking up entrepreneurship as a career. Research indicated that the course of a student which he is studying also has an influence on his decision to become an entrepreneur. The students of BHMCT, MCA and MBA/PGDM were seen to be little better inclined towards entrepreneurship than the rest of the courses. This could possibly be attributed to the presence of Entrepreneurship subject taught in the MBA/PGDM and BHMCT courses and an additional credit is due to the dot com revolution which has possibly given some boost to the entrepreneurial inclination of students with technical back ground as it requires less capital investment in comparison to other ventures. Capital investment has already been found to be a major perceived barrier among the students of Uttarakhand (Sharma \& Madan, 2013). This research has given us a direction to further explore the impact of family, society \& culture of Uttarakhand in building entrepreneurial inclination and also determine the effectiveness of university education system of Uttarakhand in building entrepreneurial inclination.

Competing interests

The authors declare that they have no competing interests. 


\section{Acknowledgment}

The authors would like to extend their gratitude to the Directors \& the Heads of various institutions of Uttarakhand who have cooperated them in this research by allowing them to interact with their students. Special thanks are also conveyed to the Director \& the Management of Quantum School of Business who have provided wholehearted support in carrying out this research.

\section{Author details}

'Quantum School of Business, 22 km Milestone, Roorkee- Dehradun Highway, Roorkee 247667 Uttarakhand, India.

${ }^{2}$ Department of Management Studies, Gurukul Kangri University, Haridwar- 247663, India.

Received: 31 May 2013 Accepted: 6 December 2013

Published: 17 February 2014

\section{References}

Ajzen, I. (1991). The theory of planned behavior. Organizational Behavior and Human Decision Processes, 50(2), 179-211.

Ashmore, MC. (1986). Entrepreneurship education makes sense. Vocational Education Journal, 61, 47-49.

Asoni, A. (2011). Intelligence, Self-confidence \& Entrepreneurship (IFN Working paper series 887) (Retrieved $15^{\text {th }}$ August, 2013 from Research Institute of Industrial Economics). website: www.ifn.se/wfiles/wp/wp887.pdf.

Bandura, A. (1986). Social foundation of thought and action: A social cognitive theory. Englewood Cliffs, NJ: Prentice Hall.

Baum, JR, Locke, EA, \& Smith, KJ. (2001). A Multidimensional Model of Venture Growth. Academy of Management Journal, 44(2), 292-303.

Bird, B. (1995). Towards a theory of entrepreneurial competency. In JA Katz \& RH Brockhaus (Eds.), Advances in entrepreneurship, firm emergence and growth. Greenwich, CT: JAI Press.

Box, TM, Watts, LR, \& Hisrich, RD. (1994). Manufacturing entrepreneurs: An empirical study of the correlates of employment growth in the Tulsa MSA and rural East Texas. Journal of Business Venturing, 9(3), 261-270.

Boyd, NG, \& Vozikis, GS. (1994). The influence of self-efficacy on the development of entrepreneurial intentions and actions. Entrepreneurship: Theory and Practice, 18(4), 63-77.

Brockhaus, RH. (1982). The psychology of the entrepreneur. In CA Kent, DL Sexton, \& KH Vesper (Eds.), Encyclopedia of Entrepreneurship. Prentice Hall: Englewood Cliffs, NJ.

Brockhaus, R, \& Horwitz, P. (1986). The psychology of the entrepreneur. In D Sexton \& R Smilor (Eds.), The art and science of entrepreneurship. Cambridge, MA: Ballinger Publishing Company.

Chandler, GN. (1996). Business similarity as a moderator of the relationship between preownership experience and venture performance. Entrepreneurship: Theory and Practice, 20(3), 51-65.

Chinonso, OU. (2010). Entrepreneurship Development through Technical and Vocational Education for Self-employment and Youth Empowerment in Africa. International Journal of Learning, 17(5), 575-590.

Collins, O, \& Moore, D. (1970). The organization makers: A behavioral study of independent entrepreneurs. New York: Meredith.

Cooper, AC, \& Dunkelberg, WC. (1984). Entrepreneurship and paths to business ownership, Paper 846, Krannert Graduate School of Management. West Lafayette, Indiana: Purdue University.

Cooper, A, \& Dunkelberg, W. (1987). Entrepreneurial research: Old questions, new answers and methodological issues. American Journal of Small Business, 11(3), 11-23. Winter.

Cooper, S, Bottomley, C, \& Gordon, J. (2004). Stepping out of the classroom and up the ladder of learning: an experiential learning approach to entrepreneurship education. Industry and Higher Education, 18(1), 11-22.

Davidsson, P. (1991). Continued entrepreneurship: Ability, need, and opportunity as determinants of small firm growth. Journal of business venturing, 6(6), 405-429.

De Wit, G. (1993). Models of self-employment in a competitive market. Journal of Economic Surveys, 7, 367-397.

De Wit, G, \& Van Winden, FA. (1989). An empirical analysis of self-employment in the Netherlands. Small Business Economics, 1(4), 263-272.

Demirel, ET, \& Tikici, M. (2010). University students' entrepreneurship evaluation of brain dominance analysis of features: Inonu university example of business administration. Department of business administration. Electronic journal of social sciences, 9(32), 221-253.

Douglass, ME. (1976). Relating education to entrepreneurial success. Business Horizons, 19(6), 40-44.

Dyer, WG, Jr. (1994). Toward a theory of entrepreneurial careers. Entrepreneurship Theory \& Practice, 19(2), 7-21.

Dyke, L, Fischer, E, \& Reuber, A. (1992). An inter-industry examination of the impact of owner experience on firm performance. Journal of Small Business Management, 30(4), 72-88.

Fayolle, A, \& Degeorge, JM. (2006). Attitudes, intentions, and behaviour: New approaches to evaluating entrepreneurship education. In A Fayolle \& H Klandt (Eds.), International Entrepreneurship Education (Issues and Newness, pp. 74-89). Cheltenham (UK): Edward Elgar.

Foley, A, \& Griffith, B. (1998). Education, training and the promotion of high quality entrepreneurs in Republic of Ireland. In M Scott, P Rosa, \& H Klandt (Eds.), Educating entrepreneurs for wealth creation. Brookfield, VT: Ashgate Publishing Company.

Gardner, H. (2006). Multiple intelligences. USA: Basic Books.

Gardner, H. (2007). Responsibility at work. USA: Jossey Bass.

Gartner, W. (1988). "Who is an entrepreneur?" Is the wrong question. American Journal of Small Business, 12(1), 11-32.

Ghazali, A, Ghosh, BC, \& Tay, RST. (1995). The determinants of self-employment choice among university graduates in Singapore. International Journal of Management, 12, 26-35.

Gilad, B, Kaish, S, \& Ronen, J. (1989). Information, search, and entrepreneurship: A pilot study. Journal of Behavioral Economics, 18(3), 217-235.

Hart, MM, Stevenson, HH, \& Dial, J. (1995). Entrepreneurship: a definition revisited. In Frontiers of entrepreneurship research, 15. 
Hartog, J, Van Praag, M, \& Van Der Sluis, J. (2010). If you are so smart, why aren't you an entrepreneur? Returns to cognitive and social ability: Entrepreneurs versus employees. Journal of Economics \& Management Strategy, 19(4), 947-989.

Hisrich, R, \& Brush, P. (1984). The woman entrepreneur: management skills and business problems. Journal of Small Business Management, 22, 31-37.

Katz, JA. (1992). A psychological cognitive model of employment status choice. Entrepreneurship: Theory and Practice, 17(1), 29-37.

Kets De Vries, MFR. (1977). The entrepreneurial personality: A person at the corssroads. Journal of Management Studies, 14(1), 34-57.

Kiesner, WF. (1984). Higher education and the small businessperson: A study of the training and educational needs, uses, and desires of the small business practitioner. Claremont Graduate School.

Kolvereid, L, \& Moen, Ø. (1997). Entrepreneurship among business graduates: does a major in entrepreneurship make a difference? Journal of European Industrial Training, 21(4), 154-160.

Kristiansen, S, \& Indarti, N. (2004). Entrepreneurial intention among Indonesian and Norwegian students. Journal of Enterprising Culture, 12(01), 55-78.

Krueger, NF, \& Brazeal, DV. (1994). Entrepreneurial potential and potential entrepreneurs. Entrepreneurship: Theory and Practice, 18, 91.

Krueger, NF, \& Carsrud, AL. (1993). Entrepreneurial intentions: applying the theory of planned behaviour. Entrepreneurship \& Regional Development, 5(4), 315-330.

Krueger, NF, Jr, Reilly, MD, \& Carsrud, AL. (2000). Competing models of entrepreneurial intentions. Journal of Business Venturing, 15(5), 411-432.

Lee, DY, \& Tsang, EWK. (2001). The effects of entrepreneurial personality, background and network activities on venture growth. Journal of Management Studies, 38(4), 583-602.

Mathews, CH, \& Moser, SB. (1995). Family background and gender: implications for interest in small firm ownership. Entrepreneurship \& Regional Development, 7(4), 365-378.

Maxwell, JR, \& Westerfield, DL. (2002). Technological entrepreneurism: characteristics related to the adoption of innovative technology. SAM Advanced Management Journal, 67(1), 9-21.

McMullen, JS, \& Shepherd, DA. (2006). Entrepreneurial action and the role of uncertainty in the theory of the entrepreneur. Academy of Management Review, 31(1), 132-152.

McStay, D. (2008). An investigation of undergraduate student self-employment intention and the impact of entrepreneurship education and previous entrepreneurial experience, ePublications@bond, Bond University, Australia.

Nishantha, B. (2009). Influence of Personality Traits and Socio-demographic Background of Undergraduate Students on Motivation for Entrepreneurial Career: The Case of Sri Lanka. Ryukoku University Economic Association (龍谷大学経済学会), 49(2), 71-82.

Noel, T. (1998). Effects of entrepreneurial education on intent to open a business: An exploratory study. Journal of Entrepreneurship Education, 5, 3-13.

Noll, CL. (1993). Planning curriculum for entrepreneurship education. Business Education Forum, 47(3), 3-6.

Oakey, RP. (2003). Technical entreprenenurship in high technology small firms: some observations on the implications for management. Technovation, 23(8), 679-688.

Othman, MN, Ghazali, E, \& Sung, YS. (2006). Graduate versus non-graduate entrepreneurs in urban Malaysia: some insights into entrepreneurial personality, company and family background differences. Journal for International Business and Entrepreneurship Development, 3(1), 57-76.

Peterman, NE, \& Kennedy, J. (2003). Enterprise education: Influencing students' perceptions of entrepreneurship. Entrepreneurship theory and practice, 28(2), 129-144.

Pomery, E, Gibbons, F, Reis-Bergman, M, \& Gerrard, M. (2009). From Willingness to Intention: Experience moderates the shift from reactive to reasoned behaviour. Personality and Social Psychology Bulletin, 35(7), 894-908.

Praag, C, \& Ophem, HV. (1995). Determinants of willingness and opportunity to start as an entrepreneur. Kyklos, 48(4), 513-540.

Reynolds, PD. (1991). Sociology and entrepreneurship: concepts and contributions. Entrepreneurship theory and practice, 16(2), 47-70.

Robinson, PB, \& Sexton, EA. (1994). The effect of education and experience on self-employment success. Journal of Business Venturing, 9(2), 141-156.

Samuelsson, M. (2001). Modeling the nascent venture opportunity exploitation process across time. Frontiers of Entrepreneurship Research. Boston, MA: Babson College.

Sanghvi, AN. (1996). Promotion of technical entrepreneurship through technical education. The Indian Journal of Technical Education, 19(2), 42-44.

Scherer, R, Adams, J, Carley, S, \& Wiebe, F. (1989). Role model performance effects on development of entrepreneurial career preferences. Entrepreneurship Theory and Practice, 13(3), 53-71.

Scott, MG, \& Twomey, DF. (1988). The long term supply of entrepreneurs: Students career aspirations in relation to entrepreneurship. Journal of Small Business Management, 26(4), 5-13.

Scott, M, Rosa, P, \& Klandt, H. (1998). Educating entrepreneurs for wealth creation. Brookfield, Vermont: Ashgate Publishing Company.

Shane, S, \& Venkataraman, S. (2000). The promise of entrepreneurship as a field of research. Academy of Management Review, 25(1), 217-226.

Shapero, A, \& Sokol, L. (1982). The Social Dimensions of Entrepreneurship. In C Kent, D Sexton, \& KH Vesper (Eds.) The Encyclopedia of Entrepreneurship. Englewood Cliffs, NJ: Prentice-Hall.

Sharma, L, \& Madan, P. (2013). Perceived barriers to youth entrepreneurship: A study of Uttarakhand state India. Vivechan International Journal of Research, 4, 42-51. http://www.journal-jger.com/content/2/1/3.

Shaver, K, \& Scott, L. (1992). Person, process, and choice: The psychology of new venture creation. Entrepreneurship: Theory and Practice, 16(2), 23-45.

Sheppard, BH, Hartwick, J, \& Warshaw, PR. (1988). The theory of reasoned action: A meta-analysis of past research with recommendations for modifications and future research. Journal of Consumer Research, 15, 325-343. 
Shrader, R, \& Siegel, DS. (2007). Assessing the Relationship between Human Capital and Firm Performance: Evidence from Technology-Based New Ventures. Entrepreneurship: Theory and Practice, 31(6), 893-908.

Simon, HA. (1979). Rational decision making in business organizations. The American Economic Review, 69(4), 493-513. Sletten, J, \& Hulaas, H. (1998). What and how should entrepreneurs be taught? Implications of different backgrounds and business goals. In M Scott, P Rosa, \& H Klandt (Eds.), Educating entrepreneurs for wealth creation. Brookfield, VT: Ashgate Publishing Company.

Small Business Administration. (2001). The small business economy: A report to the President. Washington: US Government printing office.

Smith, KS, \& Smith, RL. (2000). Entrepreneurial Finance. New York: Wiley.

Souitaris, V, Zerbinati, S, \& Al-Laham, A. (2007). Do entrepreneurship programmes raise entrepreneurial intention of science and engineering students? The effect of learning, inspiration and resources. Journal of Business Venturing, 22(4), 566-591.

Stanworth, J, Stanworth, C, Granger, B, \& Blyth, S. (1989). Who becomes an entrepreneur? International Small Business Journal, 8(1), 11-22.

Sternberg, RJ. (2004). Successful intelligence as a basis for entrepreneurship. Journal of Business Venturing, 19, 189-202

Taylor, D, \& Thorpe, R. (2004). Entrepreneurial learning: A process of co-participation. Journal of Small Business and Enterprise Development, 11(2), 203-211.

Tkachev, A, \& Kolvereid, L. (1999). Self-employment intentions among Russian students. Entrepreneurship \& Regional Development, 11(3), 269-280.

Vesper, KH. (1990). New Venture Strategies (Rev.Ed.). Englewood Cliffs, NJ: Prentice-Hall.

Wadhwa, V, Holly, K, Aggarwal, R, \& Salkever, A. (2009). The anatomy of an entrepreneur: Family background and motivation. Kansas city, MO: Kauffman Foundation of Entrepreneurship.

Wadhwa, V, Freeman, R, \& Rissing, B. (2010). Education and tech entrepreneurship. Innovations, 5(2), 141-153.

Watson, K, Hogarth-Scott, S, \& Wilson, N. (1998). Small business start-ups: Success factors and support implications. International Journal of Entrepreneurial Behavior \& Research, 4, 217-238.

Wechsler, D. (1944). The measurement of adult intelligence. Baltimore: Williams \& Wilkins.

Zikmund, WG. (2003). Business Research Methods (7th ed.). India: Cengage Learning.

doi:10.1186/2251-7316-2-3

Cite this article as: Sharma and Madan: Effect of individual factors on youth entrepreneurship - a study of

Uttarakhand state, India. Journal of Global Entrepreneurship Research 2014 2:3.

\section{Submit your manuscript to a SpringerOpen ${ }^{\circ}$ journal and benefit from:}

- Convenient online submission

- Rigorous peer review

- Immediate publication on acceptance

- Open access: articles freely available online

- High visibility within the field

- Retaining the copyright to your article

Submit your next manuscript at $\boldsymbol{\sim}$ springeropen.com 